\title{
ANALYSIS OF RETROFIT BUILDING BEHAVIOR WITH BASE ISOLATION SYSTEM USING NONLINEAR TIME HISTORY ANALYSIS
}

\author{
Yanisfa Septiarsilia, Tavio, I Gusti Putu Raka \\ Department of Civil Engineering, Institute Teknologi Sepuluh Nopember Surabaya, Indonesia
}

\begin{abstract}
Now, procedures of design for the earthquake resistance of buildings and non-building structures SNI 1726: 2012 has been approved the procedures for seismic design for buildings SNI 1726-2002. SNI 1726: 2012 refers to the development of modern seismic regulations are due to changes in tectonic plates located on the active track on the path of circumPacific and the Indian track - the Himalayas. With the enactment of the new SNI earthquake, namely SNI 1726: 2012, then all existing buildings and designed with old SNI earthquake, that is SNI - 1726-2002 should be evaluated against for the new regulations. Handling scheme for existing buildings should be made to determine and improve safety. Analysis and solutions are required to improve the safety of buildings. Retrofitting Seismic Isolation is one of the effective and practical methode to increase safety of buildings against earthquakes, because this methode can reduce the earthquake acceleration response. Retrofitting seismic isolation can not only improve the safety and functionality seismic, but also to maintain the original design. Without the need to demolish and rebuild the building, the building will remain intact. So that historic buildings and cultural heritage can still be preserved. The concept of base isolation is to decouple the upper structure from its foundation and inserting isolator which has a small horizontal stiffness. This techniques can reducing the seismic impact from the soil vibration which could be from seismic motion. This study will compare the ratio building safety for old structural design that uses SNI-1726-2002 (old) vs SNI 1726: 2012 (new). The results shows that retrofitting seismic isolation building have better performance in terms of ductility demand, natural period, and lower internal forces due to earthquake.
\end{abstract}

Keywords: performance seismic based design, retrofit building, base isolation system, non-linear seismic load, isolation ratio, time history analysis.

\section{INTRODUCTION}

With the enactment of the new SNI earthquake, namely SNI 1726: 2012, then all existing buildings and designed with old SNI earthquake, that is SNI - 17262002 should be evaluated against for the new regulations. Handling scheme for existing buildings should be made to determine and improve safety.

The basic dilemma facing a structural engineer charged with providing superior seismic resistance of a building is how to minimize interstory drift and floor accelerations. Large interstory drifts cause damage to nonstructural components and to equipment that interconnects stories. Interstory drifts can be minimized by stiffening the structure, but this leads to amplification of the ground motion, which leads to high floor accelerations, which can damage sensitive internal equipment, floor accelerations can be reduced by making the system more flexible, but this leads to large interstory drifts. The only practical way of reducing simultaneously interstory drift and floor accelerations is to use base isolation system[1].

The concept of base isolation is simple. The system decouples the building or structure from the horizontal components of the ground motion by interposing structural with low horizontal stiffness between the structure and the foundation. This gives the structure a fundamental frequency that is much lower than both is fixed base frequency and predominant frequencies of the ground motion. The isolation system does not absorb the earthquake energy, but rather deflects it through the dynamics of the system [1].
Base Isolation System is very effective solution in this case (retrofit a building). Without the need to demolish and rebuild the building, the building will remain intact. So that historic buildings and cultural heritage can still be preserved. Due to the use of Base Isolation will reduce the force of the earthquake, so the seismic force will be reduced.

\section{NLTHA ANALYSIS CONCEPT}

Nonlinear Time History analysis is dynamic analysis model of the structure where the given record seismic recordings (at least three earthquake records) and the structural response is calculated at specific time intervals. Seismic load in the loading structure which entered is the recording of ground motion of the earthquakes that have occurred. Calculation of the dynamic response of structures against earthquakes influence the plan, can be done with the dynamic analysis methods such as dynamic response analysis of nonlinear time history with an earthquake accelerogram that shown as ground motion input [2].

Based on the USGS, NLTHA scaling procedure in getting the minimum scale factor for each of the seven notes of ground motions, records minimized scale spectrum between $0.2 \mathrm{Ti}$ and $1.5 \mathrm{Ti}$, the equation for the residual is expressed as follows :

$$
\lambda=\sum_{i=1}^{n}[\overline{\mathrm{A}} i-(S F \cdot A i)]
$$

\footnotetext{
${ }^{1)}$ Master Student Department of Civil Engineering, ITS, Surabaya

${ }^{2)}$ Lecturer Department of Civil Engineering, ITS, Surabaya

Strugturent Leppartimeeftngf Civil Engineering, ITS, Surabaya
} 
Where $\mathrm{Ai}$ and $\mathrm{Ai}$ is the target acceleration spectra and records (not to scale), $\mathrm{n}$ is the period between $0.2 \mathrm{Ti}$ and 1.5 Ti, SF equation is as follows [3]:

$$
\mathrm{SF}=\left\{\sum_{i=1}^{n}[\overline{\mathrm{A}} i \cdot \overline{\mathrm{A}} i\} /\left\{\sum_{i=1}^{n}[A i \cdot A i\}\right.\right.
$$

Nonlinear Time History Analysis (NLTHA) is numerical method using the approach in the analysis. NLTHA evaluation results in the form of plastic hinge formation mechanism, Displacement, Drift, and dissipation energy that will be used in identifying possible structural failure.

\section{MOMEN CURVATURE ANALYSIS}

In this analysis, the value of moment-curvature determined negative and positive, both in the state and the state of ultimate yield of the cross beams and columns. Sectional deployed using concrete materials with the amount of flexural and shear. In this study used modeling plastic hinge model based ATC [ATC-40.1996] in which the relationship between moment and curvature can be idealized as a linear relationship with models such as Figure 1 .

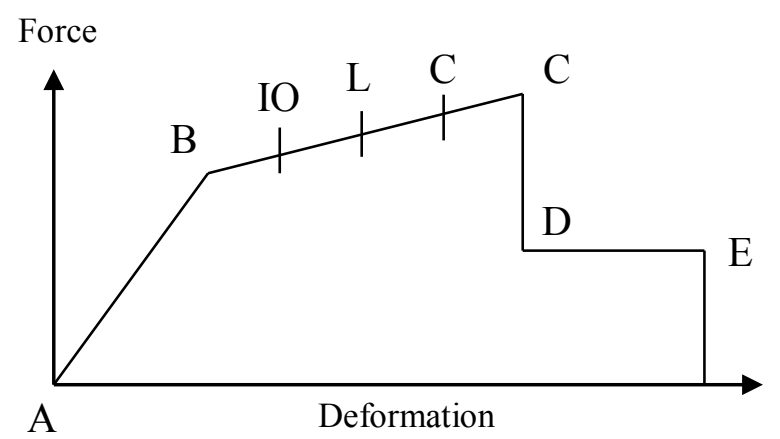

Figure 1. Force-Deformation Relationship of Plastic Hinge.

\section{GROUND MOTIONS SELECTED}

The parameters that need to be considered in identifying the scenario conditions are those that have the most influence on ground motion spectral shape are :

- Magnitude range of anticipated significant event(s)

- Distance range of the site from the causative fault(s)

- $\quad$ Site-condition (site-geology generally described by average shear-wave velocity within $30 \mathrm{~m}$ )

- Basin effect (if basin exists)

- Directivity effect

In general, events with larger magnitude yield wider response spectra. In order to find the degree of magnitude influence on response spectral shape, average spectral shapes of earthquakes ranging from magnitude 4.9 to 7.9 in the extended NGA database [4] are plotted in Figure 2.

Table 1. Selected Earthquake The Ground Motions

\begin{tabular}{|lcll|}
\hline Earthquake & Year & Station & Mag \\
\hline Imperial Valley & 1979 & El Centro Array \#7 & 6,95 \\
\hline Northridge & 1994 & Jensen Filter Plant & 6,69 \\
\hline Iran & 1978 & Tabas & 7,35 \\
\hline
\end{tabular}

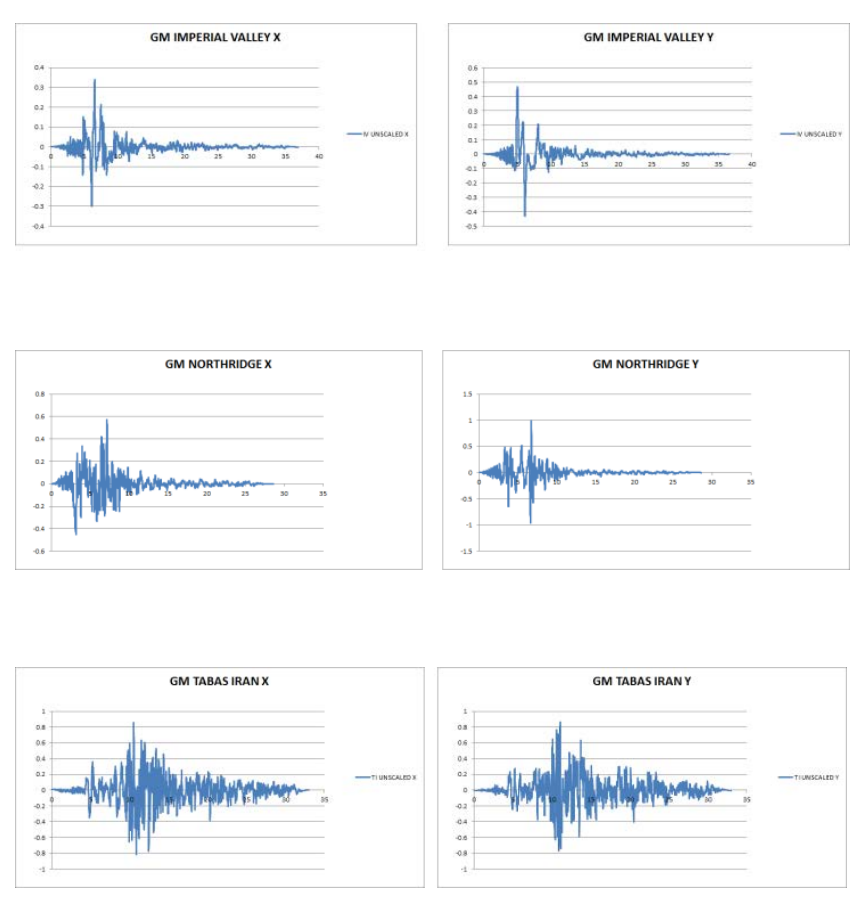

Figure 2. Selected Earthquake in X and Y Directions.

\section{MATHEMATICAL MODELING OF STRUCTURE}

Typical floor plan and elevation of base isolated 10 storey reinforced concrete structure building, which is used as the subject structure in this study as shown in Figure 3 and Figure 4 respectively. The two-dimensional model of the fixed base building and base-isolated building are made using a well-known software program SAP2000. 


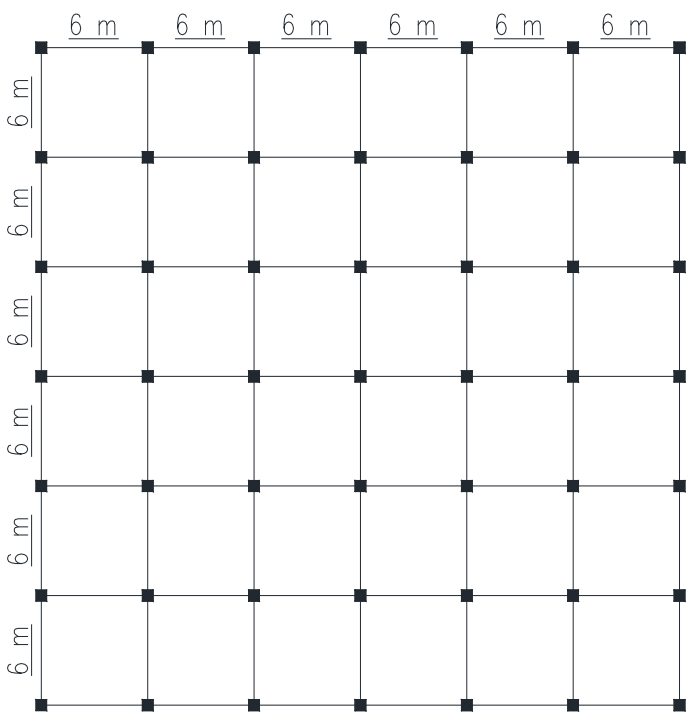

Figure 3. Typical Floor Plan

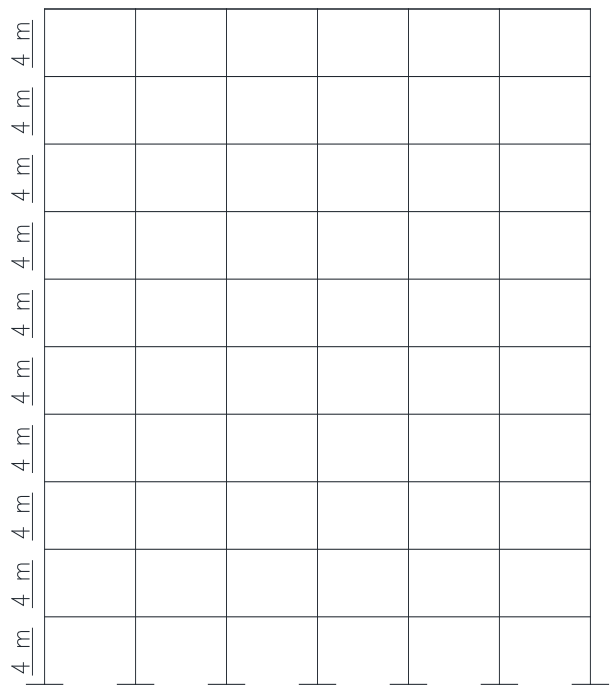

Figure 4. Elevation of Building

Fixed base have been designed according to the SNI 2002, planning in two region in Indonesia, there are Surabaya $(\mathrm{R}=3,5)$ and Aceh $(\mathrm{R}=8,5)$. A cylindrical compressive strength of $30 \mathrm{~N} / \mathrm{mm} 2$ for concrete and a yield strength of $400 \mathrm{~N} / \mathrm{mm} 2$ for steel have been assumed. The main properties of the structure are shown in Table 2 :

Table 2. Member-section dimension (with $\mathrm{x}$ depth, in $\mathrm{cm}$ )

\begin{tabular}{|lll|}
\hline Member section & Column & Beam \\
\hline Base & $60 \times 60$ & $20 \times 40$ \\
\hline $\mathbf{1 - 2}$ & $60 \times 60$ & $40 \times 70$ \\
\hline $\mathbf{3 - 4}$ & $60 \times 60$ & $40 \times 70$ \\
\hline $\mathbf{5 - 6}$ & $60 \times 60$ & $30 \times 60$ \\
\hline $\mathbf{7 - 8}$ & $60 \times 60$ & $30 \times 60$ \\
\hline $\mathbf{9 - 1 0}$ & $60 \times 60$ & $25 \times 50$ \\
\hline
\end{tabular}

Having obtained the natural period and reaction parameters perletakkan on the analysis of fixed base, then the value will be determined vertical stiffness $(\mathrm{Kv})$ and horizontal stiffness $(\mathrm{Kh})$ of the isolator device which is used to model the structure of base isolation.

$$
K_{H}=\frac{G A}{t_{r}}
$$

Where $\mathrm{G}$ is the shear modulus of the elastomer, $\mathrm{A}$ is the full cross-sectional area (which may differ from the area of the reinforcing shims), and tr is the total thickness of the rubber. The maximum horizontal displacement $\mathrm{D}$ is related to the maximum shear strain $\gamma$ by :

$$
\gamma=\frac{D}{t_{r}}
$$

The vertical stiffness $\mathrm{Kv}$ and the bending stiffness expressed as EI by analogy with beam theory are also given by a simple linear elastic theory and are needed for designing a bearing. The vertical stiffness of a rubber bearing is given by the formula :

$$
K_{V}=\frac{E_{c} A}{t_{r}}
$$

Where $\mathrm{A}$ is the cross sectional area of the bearing (in this case it usually is taken as the area of the shim plates), tr is the total thickness of rubber in the bearing, and Ec is the instantaneous compression modulus of the rubber steel composite under the specified level of the vertical load [1].

Horizontal Stiffness and Type of isolator is showing as

\begin{tabular}{|c|c|c|c|c|c|c|c|c|c|c|c|c|}
\hline odel & $\alpha$ & 11 & $\mathrm{H} 1$ & $\mathrm{H} 2$ & $\mathrm{H} 3$ & $\mathrm{H} 4$ & $\mathrm{H} 5$ & H 6 & $\mathrm{H} 7$ & KH 8 & KH 9 & KH 10 \\
\hline 1 & 1 & 0.6 & & 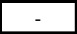 & - & & - & & 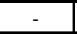 & - & & 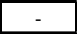 \\
\hline 2 & 1.5 & 1.9 & 8392 & 23225 & 2.28041 & 28162 & 59523 & 67557 & \begin{tabular}{|l|}
2.6773 \\
\end{tabular} & .76145 & .6349 & 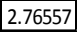 \\
\hline 3 & 2 & 1.2 & 03455 & 25564 & 1.28273 & 28341 & 45982 & 50501 & .50598 & 55331 & 55446 & 555 \\
\hline 4 & 2.5 & 1.5 & 66211 & 0.80361 & 0.82095 & 0.82138 & 0.93428 & 0.9632 & 0.96383 & 0.99412 & 0.99486 & 0.99561 \\
\hline 5 & 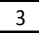 & 1.8 & 0.4598 & 0.55806 & 0.5701 & \begin{tabular}{|l|}
0.5704 \\
\end{tabular} & 0.64881 & 0.66889 & 0.66932 & 0.69036 & 0.69087 & 0.69139 \\
\hline 6 & 3.5 & 2.1 & 0.33781 & 0.41001 & \begin{tabular}{|l}
0.41885 \\
\end{tabular} & 0.41907 & 0.47667 & 0.49143 & 0.49175 & 0.5072 & 0.50758 & .5079 \\
\hline 7 & 4 & 2.4 & 25864 & 0.31391 & 0.32068 & 0.32085 & 0.36495 & 0.37625 & 0.37649 & 0.38833 & 0.38862 & 0.3889 \\
\hline 8 & 4.5 & 2.7 & 0.20436 & 0.24803 & 0.25338 & 0.25351 & 0.28836 & 0.29729 & 0.29748 & 0.30683 & 0.30705 & 0.30729 \\
\hline 9 & 5 & 3 & 0.16553 & 0.2009 & 0.20524 & 0.20535 & 0.23357 & \begin{tabular}{|l|}
0.2408 \\
\end{tabular} & 0.24096 & 0.24853 & 0.2487 & 0.248 \\
\hline
\end{tabular}
Table 3 and Figure 5 :

Table 3. Horizontal Stiffness of isolator 
The 2nd International Conference on Civil Engineering Research (ICCER) 2016

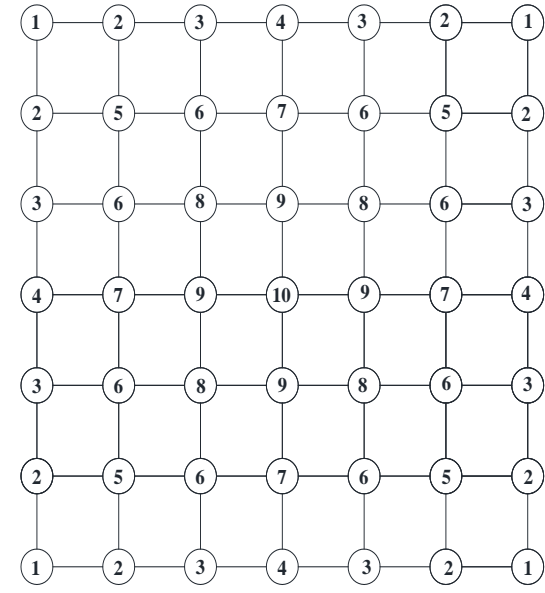

Figure 5. Type of Isolator

\section{NUMERICAL RESULT}

The structural system were subjected to sets three records modified according ASCE ground motion scaling method. The scaling process has been carried out as shown in Table 4.

Tabel 4. Scale Factor of Ground Motion

\begin{tabular}{|ccccc|}
\hline Earthquake & \multicolumn{2}{c}{ ZONA 2 } & \multicolumn{2}{c|}{ ZONA 5 } \\
& $\mathrm{X}$ & $\mathrm{Y}$ & $\mathrm{X}$ & $\mathrm{Y}$ \\
\hline El Centro & 0.80395 & 1.0884 & 1.36838 & 1.867 \\
\hline Northridge & 2.320679 & 2.800922 & 3.9666 & 4.7032 \\
\hline Iran & 0.2771 & 0.2407 & 0.4725 & 0.4044 \\
\hline
\end{tabular}

Response Spectra of Ground Motion Record that unscaled and scaled are shown below :
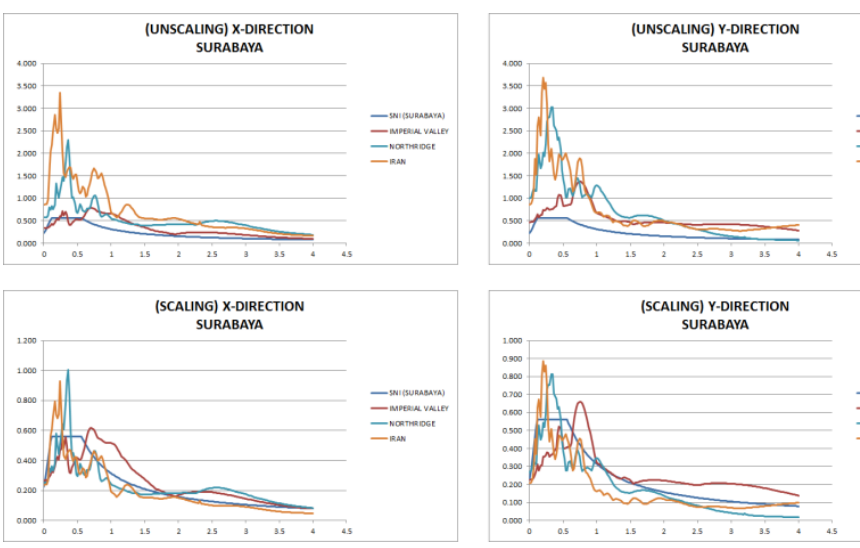

Figure 6. Response Spectra Generated of Ground Motion Records (Surabaya)
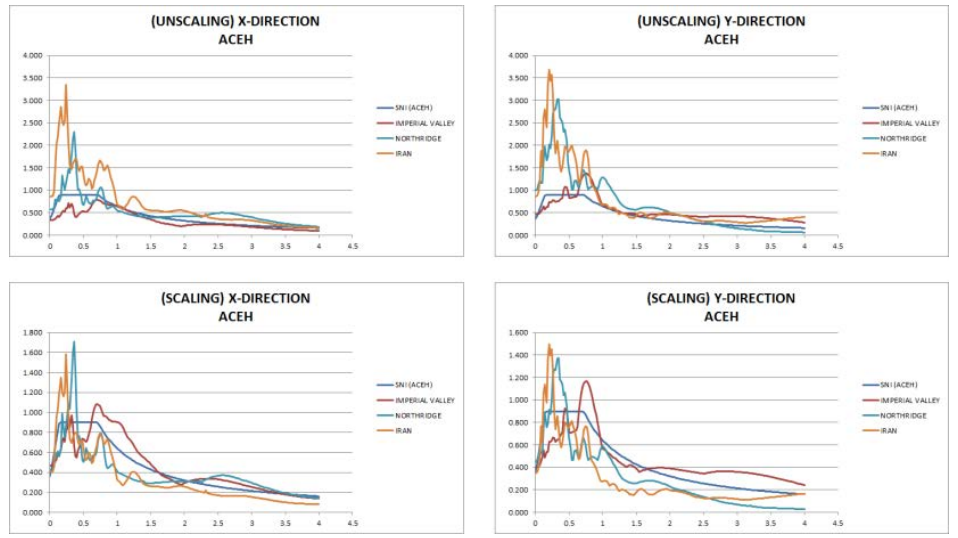

Figure 7. Response Spectra Generated of Ground Motion Records (Aceh)

\section{CONCLUSION}

The analysis of fixed base and base isolated 3-D ten storey building is performed in this paper. An exhaustive study has been performed on the performance of base isolation structures. The behavior of fixed base structure is compared with building structure resting on elastomeric bearing. Seismic base isolation can reduce the seismic effects and therefore floor acceleration, base shear, and interstorey drifts by lengthening the natural period of structure. Base isolation using elastomeric bearing between column and foundation.

This paper presents the result of NLTHA of the 10 storey building. Program SAP 2000 is used to model structure. The conclusion are :

1. Isolation ratio range 1 to 5 (i.e., for $\mathrm{Ti}=0.6-$ 3.0s)

2. The increase of isolation ratio are followed by decreasing ductility of the structure.

\section{REFERENCES}

[1]. Naeim, F., and J.M. Kelly.1999. Design of Seismic Isolated Structure from Theory to Practice. New York : John Willey \& Sons.

[2]. Pranata.2009. Analisis Dinamik Riwayat Waktu Gedung Beton Bertulang Akibat Gempa utama dan Gempa Susulan. Jurnal Dinamika Teknik Sipil UKM : 110.

[3]. Kalkan E, Chopra AK. Evaluation of Modal PushoverBased Scaling of One Component of Ground Motion: Tall Buildings. Eartquake Spectra 2012;28(4):1469-93.

[4]. Kalkan E, Grazer V.2007. Coupled tilt and translational ground motion response spectra. J Earthquake Eng 133:609-619. 